Jurnal Konstruksi Hukum | ISSN: 2746-5055

Vol. 2, No. 1, Januari 2021 Hal. 191-195 | Tersedia online di

https://www.ejournal.warmadewa.ac.id/index.php/jukonhum

DOI: https://10.22225/jkh.2.1.2993.191-195

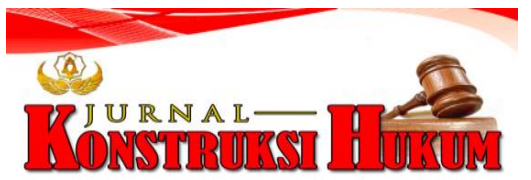

\title{
ASAS UNUS TESTIS NULLUS TESTIS DALAM TINDAK PIDANA PEMERKOSAAN ANAK
}

\author{
Ni Made Yulia Chitta Dewi, A.A. Sagung Laksmi Dewi, Luh Putu Suryani \\ Fakultas Hukum Universitas Warmadewa, Denpasar-Bali, Indonesia
}

\begin{abstract}
Abstrak
Membuktikan suatu tindak pidana pemerkosaan anak harus memiliki alat bukti yang sah. Pembuktian itu sendiri bertujuan untuk mencari kebenaran materiil guna membuktikan bersalah atau tidaknya terdakwa. Jika dalam membuktikan suatu tindak pidana pemerkosaan anak, hakim menganggap hanya ada satu keterangan saksi yang sah dan tidak didukung dengan alat bukti lainnya, tentunya hal ini akan menjadi pertimbangan putusan hakim. Penelitian ini bertujuan untuk menganalisis asas unus testis nullus testis dalam tindak pidana pemerkosaan anak dan mengetahui pembuktian tindak pidana pemerkosaan anak dengan menggunakan satu saksi (unus testis nullus testis). Jenis penelitian yang digunakan adalah penelitian normatif dan pendekatan konseptual. Hasil penelitian menunjukan bahwa keterangan saksi dalam proses pembuktian merupakan alat bukti utama sebagai pertimbangan hakim. Dalam hukum acara pidana proses pembuktian dilakukan dengan cara menghadirkan saksi dan didukungan alat bukti lainnya. Kasus tindak pidana pemerkosaan anak selain menggunakan keterangan saksi diperlukanpendukung alat bukti lainnya seperti hasil visum et repertum yang berguna untuk membuktikan suatu tindak pidana itu telah terjadi. Keterangan saksi yang berdiri sendiri harus diikuti dengan alat bukti sah lainnya, untuk memperkuat keterangan saksi tersebut. Untuk membuktikan suatu tindak pidana pemerkosaan anak, jika hanya ada satu saksi maka hal ini tidak dapat membuktikan tindak pidana telah terjadi.
\end{abstract}

Kata kunci: Unus Testis Nullus Testis, Tindak Pidana, Pemerkosaan Anak.

\begin{abstract}
Proving a criminal act of child rape must have valid evidence. The evidence itself aims to find material truth in order to prove whether the defendant is guilty or not. If in proving a criminal act of child rape, the judge considers that there is only one valid witness testimony and it is not supported by other evidence, of course this will become a consideration for the judge's decision. This study aims to analyze the principle of unus testis nullus testis in the crime of child rape and to find out the evidence of the crime of child rape by using one witness (unus testis nullus testis). The type of research used is normative research and conceptual approaches. The results showed that the testimony of the witnesses in the process of evidence was the main evidence for the judge's consideration. In criminal procedural law, the process of proof is carried out by presenting witnesses and supported by other evidence. In addition to the case of child rape, other than using witness testimony, other supporting evidence is needed, such as the results of a visum et repertum which are useful to prove that a crime has occurred. Independent witness statements must be followed by other valid evidence to strengthen the witness's testimony. To prove a crime of child rape, if there is only one witness, this cannot prove that the crime has occurred.
\end{abstract}

Keywords: Unus Testis Nullus Testis, Crime, Child Rape.

\section{PENDAHULUAN}

Adanya peraturan yang mengikat masyarakat di Indonesia tidak menjadikan masyarakat hidup dengan tertib. Banyak kejahatan merajalela akhir-akhir ini yang meresahkan masyarakat, salah satunya kejahatan pemerkosaan. Korban pemerkosaan biasanya perempuan, baik perempuan dewasa maupun anak-anak. Hal ini tentunya menjadi sorotan pemerintah karena seringnya terjadi kasus pemerkosaan. Dengan adanya hukum pidana para pelaku pemerkosaan dapat dijerat hukuman. Sebagai negara hukum Indonesia harus menjamin ketertiban dan kenyamanan untuk masyarakat serta dapat menegakkan keadilan (Husin \& Husin, 2016).

Dalam Kitab Undang-Undang Hukum Pidana (KUHP) telah mengatur secara jelas mengenai tindak pidana pemerkosaan yang pelaku dapat dijerat hukuman kurungan selama dua belas tahun. Namun hal ini tidak membuat efek jera terhadap masyarakat, masih ada beberapa masyarakat yang melakukan tindak pidana pemerkosaan. Dengan adanya aduan masyarakat yang menjadi korban 
pemerkosaan, aparat penegak hukum dapat menindaklanjuti kasus pemekosaan ini, dimulai dengan dilakukannya penyelidikan dan sampai tahap persidangan. Untuk membuktikan suatu tindak pidana pemerkosaan telah terjadi diperlukannya pengumpulan alat bukti yang sah, proses pembuktian telah dimulai sejak awal penyelidikan (Chazawi, 2011).

Dihadirkan para saksi dipersidangan guna memberikan keterangan yang diketahui oleh saksi itu sendiri bukan hanya mendengar informasi dari pihak lain. Keterangan saksi dalam persidangan dapat menjadi pertimbangan hakim dalam memutuskan suatu perkara. Menilai keterangan saksi dalam persidangan hakim haruslah bersungguh-sungguh untuk memberikan putusannya. Salah satu contoh kasus tindak pidana pemerkosaan yang terjadi di Kota Manado yang terdakwa dibebaskan karena hakim menerapkan asas unus testis nullus testis (satu saksi bukan saksi).

Dari latar belakang masalah yang telah diuraikan, penelitian ini bertujuan untuk mengetahui asas unus testis nullus testis dalam tindak pidana pemerkosaan anak dan menganalisi pembuktian tindak pidana pemerkosaan anak dengan menggunakan satu saksi (unus testis nullus testis).

\section{METODE PENELITIAN}

Penelitian ini menggunakan penelitian Hukum Normatif yang mana dilakukan dengan mengkaji studi kepustakaan berupa bahan-bahan hukum (Ahmad, 2008; Amirrudin \& Asikin, 2012). Dengan pendekatan masalah pada perundang-undangan dan konseptual. Adapun sumber bahan hukum yang digunakan berupa (a) bahan Hukum Primer yaitu dengan perundang- undangan serta putusan dari hakim yang telah memiliki hukum tetap. (b) bahan Hukum Sekunder seperti jurnal hukum, buku hukum, dan juga internet yang berkaitan dengan materi penelitian ini. (c) bahan Hukum Tersier yaitu sumber bahan hukum yang dipergunakan melalui ensiklopedia dan bahan tulis lainnya yang berkaitan dengan isu hukum yang dibahas (Marzuki, 2011). Teknik pengumpulan bahan hukum yang dipergunakan dengan cara pencatatan melalui membaca, mencatat, mengutip, meringkas, dan literatur yang berkaitan dengan bahan-bahan yang berkaitan dengan isu hukum yang dibahas. Analisis bahan hukum dengan teknik analisis bahan hukum secara sistematis. Dengan cara memilih bahan hukum dengan kualitasnya untuk membantu menjawab permaslahan yang diajukan dan mengkaitkan bahan hukum satu dengan yang lainnya.

\section{HASIL DAN PEMBAHASAN}

\section{Asas Unus Testis Nullus Testis Dalam Tindak Pidana Pemerkosaan Anak}

Saksi merupakan seseorang yang memberikan informasi dimuka persidangan guna meringankan atau memberatkan terdakwa dari tuntutannya yang mana kejadian itu didilihat, didengar, dialami sendiri oleh saksi tersebut. Adanya kehadiran saksi menjadikan alat bukti utama membuktikan suatu kejahatan. Syarat menjadi seorang saksi dibedakan menjadi dua yaitu syarat formil dan syarat materiil. Syarat formil yaitu keterangan saksi dianggap sah apabila saksi tersebut telah disumpah, saksi yang masih dibawah umur tidak dapat disumpah melainkan keterangannya hanya dapat dijadikan sebagai bahan pertimbangan oleh hakim. Syarat materiil yaitu satu keterangan saksi tidak bias dianggap sah oeh persidangan sebagai alat bukti yang sah (unus testis nullus testis).

Ketentuan asas unus testis nullus testis mengartikan jika keterangan saksi hanya berdiri sendiri tanpa dukungan alat bukti lainnya maka tidak memiliki kekuatan pembuktian. Keterkaitan keterangan saksi dengan alat bukti lainnya sangatlah penting untuk mendukung suatu pembuktian. Alat bukti sendiri merupakan segala sesuatu yang berhubungan denga suatu peristiwa yang dipergunakan sebagai bahan pertimbangan hakim dalam memutuskan suatu perkara. Alat bukti diajukan guna membuktikan tuntutan jaksa penuntut umum (Alfitra, 2011). Adapun macam-macam alat bukti yaitu: keterangan saksi, keterangan ahli, surat, petunjuk dan keterangan terdakwa. Alat bukti satu dengan yang lainnya saling mendukung, karena dalam hukum pembuktian minimumnya alat bukti harus terdapat sekurang-kurangnya dua alat bukti yang sah.

Untuk membuktikan suatu tindak pidana pemerkosaan dilakukannya proses pengumpulannya alat-alat bukti untuk mencari kebenaran materiil. Hampir semua perkara pidana diperlukannya keterangan saksi. Proses pemeriksaan saksi dimulai sejak awal penyidikan hingga penuntutan dipersidangan. Keterangan seorang saksi dapat dikaitkan dengan keterangan saksi lainnya, keterkaitan antara keterangan saksi dengan alat bukti lainnya, alasan yang diberikan saksi dalam memberikan keterangan tersebut, cara hidup saksi. 
Persesuaian keterangan saksi dengan yang lainnya dilakukan untuk meyakinkan hakim dalam memutuskan perkara, jika keterangan saksi satu dengan yang lainnya tidak ada keterkaitannya maka hakim diwajibkan untuk mengkaitkan keterangan saksi dengan alat bukti lainnya dengan sungguhsungguh memeriksa persesuaiannya. Hakim juga dapat mempertimbangkan alasan saksi dalam memberikan keterangan tersebut, dan dapat melihat cara hidup saksi yang menyangkut nilai-nilai kehidupan sosial saksi.

Dalam pemeriksaan saksi hakim, jaksa penuntut umum, dan pengacara tidak diperkenankan untuk memberikan pertanyaan yang condong untuk memberikan jawaban tertentu, saksi harus secara bebas dalam menyampaikan apa yang ia ketahui tanpa adanya tekanan dari pihak manapun (Prinst, 2002). Keterangan saksi itu sendiri merupakan alat bukti ynag utama untuk menentukan kemana arah putusan hakim, namun jika dalam persidangan hanya terdapat satu keterangan saksi (unus testis nullus testis) yang diyakini kebenarannya oleh hakim maka hakim bias mempertimbangkan kembali putusannya.

Pemeriksaan seorang saksi bertujuan untuk mengetahui seberapa luas pengetahuan yang ia dapat jabarkan di persidangan. Terkadang ada beberapa saksi yang hanya mendengar dari pihak lain (testimonium de auditu). Seperti yang diketahui syarat untuk menjadi seorang saksi yang mana ia dengar, ia lihat sendiri, yang ia alami sendiri, jika saksi hanyalah mendengar dari orang lain maka tentunya hakim bisa memberikan putusan bebas terhadap terdakwa. Sesungguhnya jika hanya terdapat satu saksi hal ini bukanlah tidak dapat dijadikan suatu pertimbangan oleh hakim yang dimaksudkan adalah keterangan satu saksi yang berdiri sendiri namun diikuti oleh keterkaitannya dengan saksi yang lain dan alat bukti lainnya tentunya keterangan saksi tersebut dianggap sah oleh hakim itu sendiri.

Biasanya dalam kasus pemerkosaan sedikit adanya saksi yang melihatkejadian tersebut, yang mana pemerkosaan biasanya dilakukan di tempat yang tidak diketahui oleh orang lain. Maka dalam hal ini, selain menggunakan keterangan saksi diperlukannya alat bukti surat yaitu hasil visum dari pihak korban yang mana hal ini akan menguatkan keterangan saksi korban dalam persidangan. Apabila pemerkosaan dilakukan oleh sekelompok orang salah satu terdakwa dapat dijadikan sebagai saksi dengan berkas perkara yang berbeda atau biasa disebut sebagai saksi mahkota, namun jika pelaku dilakukan oleh seorang diri tentunya hal ini diperlukan pendukung alat bukti lainnya.

\section{Pembuktian Tindak Pidana Pemerkosaan Anak Dengan Menggunakan Satu Saksi (Unus Testis Nullus Testis)}

Tindak pidana pemerkosaan adalah suatu perbuatan yang dilakukan oleh seorang atau sekelompok untuk melakukan hubungan seksual dengan cara memaksa dan ancaman kekerasan (Sulistiani, 2016). Pelaku pemerkosaan anak dapat diancam pidana penjara paling singkat selama 5 (lima) tahun dan paling lama 15 (lima belas) tahun dengan denda sebesar Rp.5.000.000.000,00 (lima miliar rupiah).

Untuk menunjukkan siapa pelaku pemerkosaan dilakukan dengan cara melakukan penyidikan dan penyelidikan sejak adanya laporan. Usaha untuk membuktikan suatu tindak pidana telah terjadi di muka hakim dengan mengumpulkan alat bukti sebagai bahan pertimbangan hakim untuk memutus suatu perkara disebut sebagai pembuktian (Muhammad \& Asis, 2017).

Proses pembuktian didasarkan pada alat-alat bukti yang sesuai dengan undang-undang. Pembuktian itu sendiri bertujuan untuk dijadikan suatu dasar pertimbangan hakim untuk memutus perkara dan membuktikan bersalah atau tidaknya terdakwa tersebut. Sistem pembuktian positif berdasarkan pada undang-undang hal ini dapat dilihat proses pembuktian dilihat pada alat-alat bukti yang telah disebutkan pada undang-undang dan dalam sistem pembuktian positif tidak diperlukan keyakinan hakim. Sistem pembuktian berdasarkan keyakinan hakim dapat menentukan dan mengabaikan hal lainnya jika tidak bersesuaian dengan keyakinan hakim itu, namun dalam hal ini tidak dapat memberikan terdakwa untuk mengungkapan keterangannya sebagai pembelaan terhadap dirinya. Sistem pembuktian berdasarkan keyakinan hakim dengan alasan yang logis yang dimaksudkan adalah hakim dengan bebas menyebutkan berdasarkan keyakinan yang ia ketahui, dan yang terakhir sistem pembuktian berdasarkan undang-undang secara negatif dalam hal ini hakim tidak diperkenankan menjatuhkan putusannya apabila dengan sekurang-kurangnya dua alat bukti yang sah dan hakim telah memperoleh keyakinan bahwa terdakwa terbukti bersalah melakukan tindak pidana.

Kekuatan dan penilaian alat bukti untuk membuktikan tindak pidana pemerkosaan anak harus dilengkapi dengan alat bukti lainnya. Biasanya kasus pemerkosaan sulit mencari alat bukti 
dikarenakan korban hanya seorang diri tanpa ada saksi yang melihat. Salah satu contoh kasus pemerkosaan anak terjadi di Kota Manado dengan korban anak-anak Friska Simbar (14 Tahun), terdakwa Felix Lengkey (40 Tahun). Korban mengaku telah dipaksa untuk melakukan hubungan badan dengan terdakwa saat rumah terdakwa dalam keadaan sepi, jaksa penuntut umum menghadirkan saksi dari pihak korban sebanyak 4 (empat) orang dan saksi dari pihak tersangka.

Bahwa keterangan saksi-saksi yang dihadirkan, saksi hanya memberikan keterangan yang mana dia hanya dengar dari korban saja tidak melihat atau mendengar kejadian tersebut. Salah satu saksi yang dihadirkan juga sebelumnya pernah memiliki masalah pribadi dengan terdakwa dan keterangan saksi-saksi korban tidak memiliki keterkaitan melainkan masing-masing keterangan saksi berdiri sendiri tanpa didukung alat bukti lainnya. Dari keterangan-keterangan saksi, diketahui bahwa korban sudah pernah diperkosa oleh pamannya beberapa tahun yang lalu.

Keterangan saksi dari terdakwa menyebutkan bahwa terdakwa jarang berada dirumah, dan sering berpergian kota. Terdakwa hanya pulang pada malam hari atau sore harinya, dan terdakwa membantah semua tuduhan yang dituduhkan padanya. Terdakwa tidak pernah menyuruh korban untuk menggaruk punggung terdakwa, terdakwa juga mengakui bahwa penisnya sudah tidak berfungsi beberapa tahun terakhir. Berdasarkan keterangan saksi yang dihadirkan jaksa penuntut umum tidak dapat membuktikan bahwa tindak pidana pemerkosaan itu telah terjadi. Korban memberikan kesaksiannya dengan meyebutkan bahwa alat kelamin tersangka terdapat tahi lalat yang berwarna coklat namun hal ini tidak bisa dibuktikan karena saat majelis hakim memeriksa alat kelamin terdakwa dalam sebuah ruangan khusus tidak terdapat tahi lalat berwarna coklat seperti yang diutarakan oleh korban.

Dari hasil visum et repertum tampak robekan-robekan lama pada selaput dara korban, hal ini dapat dikesampingkan mengingat korban pernah diperkosa oleh pamannya. Maka hasil visum et repertum tidak dapat membuktikan bahwa terdakwa telah melakukan pemerkosaan. Mengingat bahwa terdakwa tidak terbukti melakukan tindak pidana yang di dakwakan, maka terdakwa dinyatakan tidak terbukti secara sah dan meyakinkan bersalah melakukan tindak pidana. Dalam hal ini hakim menerapkan asas unus testis nullus testis (satu saksi bukan saksi). Kesaksian yang dihadirkan oleh penuntut umum tidak memiliki keterkaitan antara keterangan saksi yang satu dengan yang lainnya. Saksi yang dihadirkan hanyalah mendengar dari orang lain bukan melihat, mendengar dan mengalaminya sendiri. Seperti yang telah diketahui, bahwa syarat keterangan saksi ialah ia lihat sendiri, ia dengar sendiri, dan ia alami sendiri sedangkan keterangan saksi yang dihadirkan tidak mengalami sendiri namun hanya mendengar dari orang lain atau disebut dengan testimonium de auditu. Hanya keterangan saksi korban yang dapat dijadikan pertimbangan hakim untuk memutus perkara, dan keterangan saksi korban tidak memiliki keterkaitannya terhadap salat bukti lainnya.

Seperti yang telah diketahui jika hanya terdapat satu orang saksi maka alat bukti tidak mempunyai kekuatan pembuktian. Dalam sistem pembuktian, jika hanya terdapat satu alat bukti maka tidak mempunyai kekuatan hukum yang tetap. Hal ini telah tercantum dalam pasal 185 ayat (2) KUHAP yang mana keterangan seorang saksi saja tidak cukup untuk membuktikan bahwa terdakwa bersalah terhadap perbuatan yang didakwakan kepadanya. Hakim dapat mempertimbangkan putusannya jika alat bukti kurang dan keterangan saksi satu dengan yang lainnya tidak berhubungan. Maka dalam hal ini hakim memutuskan bahwa terdakwa tidak terbukti melakukan kesalahan dan bebas dari segala tuntutannya.

Menurut pendapat peneliti, seperti yang telah di jelaskan sebelumnya, untuk membuktikan kesalahan terdakwa haruslah di buktikan dengan minimum dua alat bukti yang sah. Maka dalam putusan No.35/Pid.Sus/2015/PN.Arm, hakim membebaskan terdakwa dari segala dakwaan yang didakwakannya yang dikarenakan hakim penerapkan asas unus testis nullus testis. Meneliti bunyi pasal 183 KUHAP dengan kalimat dengan sekurang-kurangnya dua alat bukti yang sah, hal ini dimaksudkan menjatuhkan pidana kepada terdakwa boleh dilakukan hakim apabila kesalahan terdakwa telah dapat dibuktikan dengan sekurang- kurangnya dua alat bukti yang sah. Dalam kasus tindak pidana pemerkosaan di Kota Manado tersebut, hanya diperoleh keterangan satu saksi. Yang mana satu saksi tidak dianggap mempunyai kekuatan pembuktian yang kuat, atau disebut dengan satu saksi bukan saksi (unus testis nullus testis). Jadi minimum pembuktian yang dianggap cukup membuktikan kesalahan terdakwa agar dapat dijatuhkan pidana, harus dengan sekurang-kurangnya dua alat bukti yang sah. Satu alat bukti saja undang-undang belum menganggap cukup untuk membuktikan kesalahan terdakwa. 


\section{SIMPULAN DAN SARAN}

\section{Simpulan}

Mencari kebenaran materiil dalam kasus tindak pidana pemerkosaan anak diperlukan adanya minimum dua alat bukti yang sah agar memperkuat keyakinan hakim. Banyak kasus pemerkosaan biasanya dialami oleh satu orang tentu hal ini untuk membuktikannya perlu ada dukungan alat bukti lainnya seperti hasil visium, keterangan korban, dan keterangan terdakwa. Jika dalam persidangan hakim hanya menganggap hanya ada satu keterangan saksi yang dianggap sah tentunya hal ini akan menjadi pertimbangan hakim seperti yang diketahui satu saksi bukan saksi (unus testis nullus testis). Selanjutnya, asas unus testis nullus testis dalam membuktikan pemerkosaan tidak bisa membuktikan bahwa terdakwa terbukti bersalah, jika dalam persidangan telah dihadirkan lebih dari satu orang saksi namun keterangan saksi satu dengan yang lainnya tidak berkaitan, dan saksi hanya mendengar dari orang lain maka hakim tidak diperkenankan untuk menggunakan keterangan saksi tersebut dan hakim akan menerapkan asas unus testis nullus testis yang mana hakim hanya menganggap hanya ada satu saksi dan terdakwa yang didakwakan penuntut umum tidak akan terbukti karena tidak memiliki kekuatan pembuktian.

\section{Saran}

Mengenai hal membuktikan kebenaran materiil pengecualian untuk kasus tindak pidana pemerkosaan seharusnya diperkenankan untuk menggunakan satu saksi sehingga jika terdakwa di bebaskan dari hukuman dan kejahatan itu benar adanya maka korbanlah yang merasa tidak mendapatkan keadilan. Mengenai satu saksi bukan saksi (unus testis nullus testis) dalam membuktikan tindak pidana pemerkosaan diperlukan adanya dukungan alat bukti lainnya yang harus terkumpul jika mengalami pemerkosaan dan segera mengadukan hal ini terhadap pihak yang berwajib agar segera menyelesaikan kasus kejahatan pemerkosaan yang marak terjadi saat ini.

\section{DAFTAR PUSTAKA}

Ahmad, B. (2008). Metode Penelitian Hukum. Bandung: Pustakasetia.

Alfitra. (2011). Hukum pembuktian dalam beracara pidana perdata dan korupsi di Indonesia. Jakarta: Raih Asa Sukses.

Amirrudin, \& Asikin, Z. (2012). Pengantar Metode Penelitian hukum, . Jakarta: PT. Raja Grafindo Persada.

Chazawi, H. A. (2011). Hukum Pembuktian Tindak Pidana Korupsi. Malang: Banyumedia Publishing.

Husin, K., \& Husin, B. R. (2016). Sistem Peradilan Pidana Di Indonesia. Jakarta: Sinar Grafika.

Marzuki, P. M. (2011). Penelitian Hukum. Jakarta: Kencana Prenida Media.

Muhammad, A. S., \& Asis, A. (2017). Hukum Acara Pidana Edisi Kedua. Jakarta: Kencana.

Prinst, D. (2002). Hukum Acara Pidana Dalam Praktik Edisi Ketiga. Jakarta: Djambatan.

Sulistiani, S. L. (2016). Kejahatan dan Penyimpangan Seksual Dalam Persepektif Hukum Islam dan Hukum Positif Indonesia. Bandung: Nuansa Aulia. 